\title{
10
}

\section{How should School Managers be Trained for Managerial School Information System Usage?}

\author{
A.J. Visscher and E.M. Branderhorst \\ University of Twente, Faculty of Educational Science and Technology, Department of \\ Educational Organisation and Management
}

Key words: Training, School Management, Information System, Utilisation

Abstract: $\quad$ Although there is strong empirical evidence of the extent to and ways in which school staff have been trained for school information system usage, a solid basis for designing such training courses is lacking. In this study the literature from three disciplines of study have been analysed as a basis for systematically designing training courses. The results show that in these courses account should be taken of(1) the specific characteristics of adults and the way in which their learning activities prove to be most successful; (2) the nature of school management work; and (3) the skills, attitudes and new roles the utilisation of ICT in school management presupposes.

\section{INTRODUCTION AND PROBLEM STATEMENT}

Despite the fact that most secondary schools in developed countries use computer-assisted school information systems for the operation of their organisations, they tend to utilise these systems in the clerical area. Although this type of assistance is very important and most probably leads to valuable efficiency improvements, it is unacceptable that school managerial work receives so little support (Ayres et al., 1998; Dale \& Habib, 1991; Visscher, 1992; Visscher et al., 1999; Visscher \& Bloemen, 1999 \& 2001). Management information systems not only enable the efficient execution of routine data processing work, non-routine managerial work can also increase in quality and as such improve school effectiveness.

There is also a more specific reason for attempting to increase the managerial usage of modern school information systems. The need for 
informed policy-making has become very important and will most probably become even stronger as schools in many countries receive more discretion to develop their own school policies. This growing school autonomy implies that schools now need to develop plans in areas where they formerly executed policies developed at national levels. Filling out this new room for policy-making requires that school staff acquire information on which they can base their plans and decisions. Computerised information systems can assist here by providing valuable management information.

There is strong empirical evidence that user training strongly influences the degree ofinformation systemusage (Fulmer, 1996; Fung, 1992; Visscher et al., 1999; Visscher \& Bloemen, 2001). Little is known however about the ideal contents of courses to train school managers in information system usage. The goal of this research project is to build a basis for the design of such training courses to accomplish the full utilisation of computerised school information systems at school managerial level. Its central question may be formulated as follows:

Which characteristics should a training course have, in terms of contents and instructionalfeatures, to promote the managerial usage of computersupported school information systems successfully?

The answer is based on literature research from three different perspectives:

- The introduction of management information systems in the business sector;

- The implementation of information and communication technologies in education, especially the introduction of computer-assisted school information systems; and

- Literature on strategies for training adults.

\section{RESULTS}

The business sector has a much longer tradition of developing and implementing management information systems than the educational sector. The first systems for management reporting were introduced into corporations in the 1960s. Thereafter, decision support systems and so-called executive information systems were developed and installed. None of these three systems was a great success (Koers, 1993; Waal \& Bulthuis, 1995). The management reporting systems proved to produce far too much data and bury managers under it. Using decision support systems required much time and specific expertise, whereas executive information systems did not prove 
to be the answer because of difficulties with data retrieval and the mismatch between the data produced and the data managers need. An important prerequisite for successfully introducing information systems is the development of a system that matches with the nature of managerial work in general, and the information needs of managers more specifically. At the same time the determination of these information needs proves to be very difficult (in part because managers can not indicate their needs very well) and to a certain degree undesirable because it reinforces the status quo and does not result in new types of(information) management (Ackoff, 1967; Bemelmans, 1984; Koers, 1993).

Developing performance indicators has been a popular strategy for dealing with the problem that information systems frequently spit out a lot of - too often inaccessible - information, of which the larger part is irrelevant and burdens managers instead of helping them (Baarda et al., 1995; Waal \& Bulthuis, 1995). An important advantage of these indicators is that their number is limited and they provide managers with information that quickly shows how the organisation functions. An interesting and not easy answerable question is which indicators would provide reliable and valid information on school organisational functioning, if one would follow the performance indicator approach.

The second source of inspiration for the design of training courses for promoting managerial system usage concerns the experience gained with introducing information and communication technology (ICT) into schools.

The literature on ICT in education is enormously wide. Many publications however contain visionary articles on the role and impact of ICT, which are in strong contrast with reality in the average school where the student-computer ratio is low (e.g. 65 computers in the average Dutch secondary school). Moreover, the hardware is often old and as a result does not support the modern applications. The software schools possess is often characterised by serious limitations and does not match with the existing curriculum. Although most schools have a computer network, access to the school network (e.g. from teachers' houses) and connections with the external world (for example the use of internet) are often a problem. In the majority of schools, a school ICT plan is lacking, and where there is one, it usually addresses the use of ICT for instruction and clerical work. Attention for managerial types of ICT usage is rare (Brummelhuis, 1998).

Visscher (1991) makes a distinction between four groups of factors influencing the impact of information system usage: the system design strategy, the resulting quality of the system, the implementation strategy, and the features of the organisation into which the system is being introduced. Since our focus is on which characteristics training courses for managers should have, we assume a given design strategy and resulting information 
system. What remains concerns the desirable features of the implementation process and the extent to which the various ways of system usage match with the nature of the school as an organisation (and more specifically, the match with the information needs of school managers). User training, as stated before, proves to be of utmost importance. In two large scale studies in Hong Kong and The Netherlands, a few critical success factors for information system usage have been found. In the latter study, the amount of the school's internal and external training, and the clarity of the means to accomplish the innovation, proved to be the most powerful explanations for variance in system usage. In the Hong Kong study the start motivation of users, their perception of the quality of the information the system produces, the amount of computer experience and user training, and the innovation clarity accounted for $36 \%$ of variance in information system use by clerical staff.

These results not only stress the importance of training, they also give some indications for the contents of training: try to motivate users for system usage from the start, train them to master specific computer skills, point clearly to what the training goals are, and explain which way it will be attempted to accomplish these goals. The training of school managers, if any, is usually very limited (often not more than 10 hours), too technical and too theoretical (Visscher \& Bloemen, 2001).

On the other hand, early success experiences of target users participating in an innovation prove to encourage and promote implementation success strongly (Akker et al., 1992). Akker et al. also stress that, as a start, those performing an implementation should reflect on what information system usage by school managers assumes and thereafter train users in the areas where teachers lack knowledge, skills or do not have the desired attitude. Akker et al. also think that examples of good system usage (including what to do with the information for organisational management), manuals and answers to FAQ are necessary for successful implementation.

Fullan et al. (1988) have published on the way in which IT usage by teachers may be stimulated. Because of important similarities between the problems of implementing IT for instruction and for managerial purposes, their work may be translated to our central problem. Fullan et al., apart from hardware and software related matters, argue that IT instruction should teach school managers the required skills, influence their attitude in such a way that they value system usage, let them acquire the confidence that they 'can do it', and arrange that colleagues learn from each other as much as possible (multiplier strategies). Furthermore, Fullan et al. propose systematic and continuous support. Learned behavior should be transferred to the job. Baldwin and Ford (1988) defined this as 'positive transfer': the degree to which trainees effectively apply knowledge, skills and attitudes, gained in a training context, to their jobs. Several factors influencing transfer have been 
proposed by authors (Baldwin \& Ford, 1988; Gielen, 1995; Seyler et al., 1998). Follow-up support, the design of a training course, the trainee characteristics, as well as the organisational environment affect transfer. On the basis of the literature, the following guidelines can be formulated regarding how transfer can be promoted (Gielen, 1995; Ouden, 1992; Seyler et al., 1998):

- Gain support for training from trainees, peers and supervisors;

- Conduct needs assessments as a basis for designing training courses;

- Create task similarity between training courses and work;

- Address trainee characteristics such as ability, motivation and learning style;

- Offer varied contexts and stimulate generalisation to make knowledge less context-bound;

- Trainees should have the opportunity to practice the newly learned skills in the job;

- Organise follow-up support.

What about the fit between the characteristics of school information systems and the organisational nature of schools? In the literature, schools are not portrayed as powerful policy-makers; developing school policy measures seems to be difficult, the execution of measures taken even more so (Marx, 1986).

Various types of computer-produced information can be used in school decision-making on so-called unstructured problems. Problem diagnosis and the search for solutions are crucial in dealing with these type of problems, which may be supported by the output from information systems in five ways (Visscher, 1996):

- Analysing relationships between variables, e.g. between truancy and student achievement; achievement and lesson drop out;

- Analysing patterns over time, e.g. in student intake, staff illness, truancy over several years;

- Answering what-if questions, e.g. how many students will be promoted if the promotion criteria are raised? How much money will we get if the number of students decreases by $\mathrm{x} \%$ ? How many teaching staff will be needed if $\mathrm{x}$ students are promoted?;

- Policydevelopment based on information system produced information; and

- Information system based policy evaluation, e.g. to what extent has the percentage of grade repeaters increased after the promotion criteria were 
adapted? Has truancy increased after the timetable was changed? What was the effect of extra mathematics lessons on student achievement?

School managers are not the stereotypical rational problem solver who, facing an organisational problem, carefully analyses it, generates alternative solutions and thereafter elaborates the one preferred. They prefer informal face-to-face information (including gossip and speculation) instead of formal reports containing aggregated computer data. Obtaining information quickly seems to be more important than getting high quality information.

Even if school managers are motivated for information system usage it will be a while before they achieve this. They, for instance, have to acquire new skills:

- Determining what type of information they need for their work, or for a specific problem;

- How they can get the information from their school information system;

- How it should be interpreted; and

- How it should be used in their decision-making and policy-evaluation activities (Visscher, 1996).

Too often too much and useless information is collected and processed. The fact that computers can process data very quickly may even increase this phenomenon. Selection of what is needed is therefore crucial. If this is clear, managers or their colleagues should be able to retrieve the information from the system, which may not be easy if this requires the definition of a software query.

School managers are not experienced in interpreting aggregated computer data and therefore will have to learn to determine what the data say and what is not said.

Based on the work of Romiszowski (1981), the stages in the development of the above mentioned skills can be summarised as follows:

1. Offer knowledge of what should be done, to what purpose, in what sequence and how.

2. Let them watch you do it.

3. Let them do the simple parts of thejob.

4. Let them do the wholejob, but observe them.

5. Put them on their own and offer a greater range of job-related applicationsituations.

The third and last perspective for analysing the literature concerns the research on training adults. Some general characteristics of adult learners are 
being mentioned in the literature (Buckley, 1990; Knowles, 1978; Rogers, 1977; Thijssen \& Greef, 1989):

- Participants voluntarily participate in training activities;

- Participants desire to influence the training contents and the way they will be trained, to ensure that the training matches their desires;

- The training makes use of and builds on the experiences adults have already gained; and

- There is a need for a safe environment in which experimentation is encouraged.

It is very important for trainers to bear these characteristics of adult learners in mind when preparing new materials. Above all, learners must 'own' the problem and have a positive attitude. The attitude of the school manager is critical. Unrealistic, negative attitudes may result in a lack ofreception of the new learning, or even in active opposition to its use (Turnipseed \& Burns, 1991). Managers have to recognise that the new learning is both relevant and necessary, and they need to be challenged by:

- A training session that immediately challenges and motivates participants;

- Training that begins with the learners' own experience and builds upon that;

- An 'open' climate, i.e. a positive environment where learning is regarded as valuable;

- Materials and methods that encourage active participation. Listening passively to others can be useful as a means of raising awareness levels, however it is seldom effective as a means of acquiring skills and changing attitudes or behaviour; and

- Opportunities for peer learning and feedback on performance.

The previous is in line with the work of Kolb (1984), an important representative of the experiential learning movement. He distinguishes between four learning phases that have to be completed to make learning useful:

- Action andreal experience (whathappens?);

- Observation and reflection (what happened and why did it happen?);

- Analysis and abstraction (what does it mean and what have I learnt?); and

- Modification and new action (what is going to happen next time?). 
The realistic nature of the learning situation can be increased by having an experienced principal participate as an expert in dealing with a case, choosing active instructional activities, and small groups.

\section{CONCLUSION}

So far, neither in the business sector nor in the public sector, has managerial support by computer-assisted information systems proved to be an enormous success. There is a strong under-utilisation of the potential of information systems at that level. In the business sector this has led to the performance indicators trend: developing critical success indicators to prevent managers being buried under computer-data, and providing them with crucial information on how their organisations perform. This might be a way to operate in the school management world as well. An additional problem is that in schools decisions are often taken ad hoc; the systematic development of an explicit school-policy is rare. The full utilisation of the management support capabilities of information systems therefore requires that schools develop as organisations. School staff need to develop a number of skills:

- To recognise the value of information systems, and to develop a school informationsystempolicy;

- To determine what type of information they need for their work, or for a specificproblem;

- To discover how they can get the information from their school informationsystem;

- To learn how it should be interpreted; and

- Touse it in their decision-making and policy-evaluation activities.

It is important that the training contents is in line with an analysis of what information system usage requires, in terms of attitudes, skills, and organisational roles. The probability of experiencing early success should be as great as possible. Moreover, the target users should be taught how user problems can be prevented as much as possible and how, if problems occur, they can be dealt with.

The literature on adult learning shows that successful learners have a positive attitude towards innovation and learning, and desire to achieve the learning goals. Their attitude and motivation are encouraged by clear training goals and strategy, and by examples that show the benefits of what is being learned. Training should also give them the confidence that they can master the skills. 
Other factors that seem to be important for training adults:

- Involve the learners in decisions about the learning objectives, methods and materials ('ownership');

- Relate new material to what the adults already known;

- Provide experience reflection learning (real experience, reflection, abstraction and new action);

- Create a positive, open and safe learning environment with opportunities for peer learning;

- Include 'experts' in thetraining program;

- Provide unequivocal documentation (on paper or a FAQ page on the Internet); and

- Arrange conditions under which transfer can be enhanced, e.g. match with the characteristics of the trainees (motivation, ability), gain support for the training activities and organise follow-up training sessions.

The trainer should not fulfil the role of information provider, so much as operate as a coach for the learner: in co-operation with the group the trainer determines the course contents, takes account of trainees' specific situation, and coaches and stimulates them. The group should be small (e.g. 7-10 people), providing opportunities for all members to participate and learn from each other.

\section{REFERENCES}

Ackoff, R.L. (1967). Management MIS Information Systems. Management Science, 14 (4).

Akker, J. van den, Keursten, P., \& Plomp, T. (1992). The integration of computer use in education. International Journal of Educational Research, 17, 65-76.

Ayres, D., Nolan P., \& Visscher, A. (1998). Computerized school information systems: Researching NewZealand use patterns and levels ofuse. In C. Fulmer, \& P. Nolan (Eds.), The integration of information for educational management. Whitefield, Maine: Felicity Press.

Baarda, P.R., Kouwenhoven, C.P.M., \& Werkhoven, J.A. (1995). Ken en stuurgetallen voor personeelsmanagement [performance indicators for personnel management]. Deventer: Kluwer Bedrijfswetenschappen.

Bemelmans, T.M.A. (1984). Bestuurlijke informatiesystemen en automatisering [Administrative information systems and automation]. Leiden: H.E. Stenfert Kroese B.V.

Buckley, J. (1990). Implementing management training in secondary schools: A guide for inservice coordinators and tutors. London: Macmillan Education.

Brummelhuis, A.C.A. ten (1998). ICT-monitor 1997/1998 Voortgezet ondenwijs [ICT-monitor 1997/1998 secondaryeducation]. Enschede: Universtiteit Twente, OnderzoekCentrum Toegepaste Onderwijskunde (OCTO).

Baldwin, T.T., \& Ford, J.K. (1988). Transfer of training: A review and directions for future research. Personnel Psychology, 41, 63-105. 
Dale, D.M., \& Habib, A.G. (1991). Administrative computing in the Australian educational system. Journal of Research on Computing in Education, 24 (1), 120-145.

Fullan, M.G., Miles, M.B., \& Anderson, S.E. (1988). Strategiesfor implementing micro computers in schools: The Ontario case. Ontario: Ministry of Education of Ontario.

Fulmer, G.L. (1996). Training school administrators to use information systems: A review of research. International Journal of Educational Research, 25 (4), 351-361.

Fung, A.C.W. (1992). Management of educational innovation: The case of computer-aided administration (PhD Thesis). London: University of London Institute of Education.

Gielen, E.W.M. (1995). Transfer of training in a corporate setting (Doctoral Thesis). Enschede: CopyPrint 2000.

Knowles, M.S. (1978). The adult learner: A neglected species. Houston: Gulf.

Koers, A.J.L. (1993). Op het scherp van de snede: Overleven met Management Support Systems [At daggers drawn: Surviving with management support systems]. Amsterdam: Giarte Publishing.

Kolb, D.A. (1984). Experiential learning: Experience as the source of learning and development. Englewood Cliffs, New Jersey: Prentice Hall.

Marx, E.C.H. (1986). Meer autonomie in het onderwijs: Een ontwikkelingsmodel [More autonomy: A developmental model]. Vrijspraak, 9.

Ouden, M.D. den (1992). Transfer na bedrijfsopleidingen: Een veldonderzoek naar de voornemens, sociale voornemens, sociale normen, beheersing en sociale steun bij opleidingstransfer [Transfer of corporate training: A field study on the role of(social) plans, social norms, control and support in the transfer of training] (Doctoral Thesis). Amsterdam: Thesis Publishers.

Rogers, J. (1977). Adults learning. Milton Keynes: Open University Press.

Romiszowski, A.J. (1981). Designing instructional systems. Decision making in course planning and curriculum design. Londen: Kogan Page.

Seyler, D.L., Holton III E.F., Bates, R.A., Burnett, M.F., \& Carvalho, M.A. (1998). Factors affecting motivation to transfer training. International Journal of Training and Development, 2 (1), 2-16.

Thijssen, J.G.L., \& Greef, I. de. (1989). Het leren van volwassenen: Theorieën en grondprincipes [How adults learn: Theories and basic principles]. InJ.W.M. Kessels, \& C.A. Smit (Eds.), Handboek opleiders in organisaties. Deventer: Kluwer Bedrijfswetenschappen.

Turnipseed, D.L., \& Burns, O.M. (1991). Contemporary attitudes toward computers: An explanation of behavior. Journal of Research on Computing in Education, 23(4), 611-625.

Visscher, A.J. (1991). School administrative computing: A framework for analysis. Journal of Research on Computing in Education, 24 (1), 1-19.

Visscher, A.J. (1992). Design and evaluation of a computer-assisted management information system for secondary schools (PhD Dissertation). Enschede: University of Twente, Department of Educational Science and Technology.

Visscher, A.J. (1996). The implications of how staff handle information for the usage of school information systems. International Journal of Educational Research, 25 (4), 323334.

Visscher, A.J., \& Bloemen, P.P.M. (1999). Evaluation and use of computer-assisted management information systems in Dutch schools. Journal of Research on Computing in Education, 32 (1), 172-188.

Visscher, A.J., \& Bloemen, P.P.M. (2001). School managerial usage of computer-assisted school information systems: A comparison of good practice and bad practice schools. In P. Nolan, \& A. Fung (Eds.), Institutional improvement through information technology in educational management. London: Kluwer. 
Visscher, A.J., Fung, A., \& Wild, P. (1999). The evaluation of the large scale implementation of a computer-assisted management information system in Hong Kong schools. Studies in Educational Evaluation, 25, 11-3 1.

Waal, A.A. de, \& Bulthuis, H. (1995). Cijfers zeggen niet alles [Figures do not tell you everything]. Deventer: Kluwer Bedrijfswetenschappen. 